\title{
DO MANDADO DE SEGURANÇA CONTRA ATO JURISDICIONAL NO DIREITO BRASILEIRO
}

\author{
ARY FLORENCIO GUIMARÃES \\ Catedrático de Direito Judiciário Civil
}

16*. Verifica-se, dêsse modo, que não existem, a rigor, na sistemática do Magno Estatuto brasileiro, poderes privilegiados ou não sujeitos às regras jurídicas, cujo conteúdo idealístico tende sempre ao resguardo do bem comum, segundo os princípios de organização democrática.

As funções executivas, legislativas e judiciárias, compreendendo tôda a gama de atividades do Estado contemporâneo, estão dispostas, no ordenamento jurídico-constitucional brasileiro, num plano de isonomia, cada uma das quais exercitada, porém, consoante as normas de competência dos órgãos estatais.

Observe-se que o Estado, como um todo orgânico, visa ao bem estar e à segurança dos indivíduos enquadrados em sua estrutura político-administrativa. A distinção dos podêres, como já acentuámos, é antes um critério de desdobramento funcional, para o fim alto e superior da realização dos encargos vinculados à grande oficina de planejamento e trabalho, que é a Administração Pública, nas três zonas de presença do Estado Federal, com todos os organismos previstos para o completo desempenho dos seus mistéres.

$\mathrm{E}^{\prime}$ claro que o Poder Executivo, encarregado de prover à execução dos serviços públicos, em vista, principalmente, das exigências crescentes de intervenção do Estado nos vários domínios, é o poder que mais comumente, bem por isso mesmo, ensêja a matéria prima para o contrôle judicial dos atos que exorbitem dos lindes da legalidade, incluído neste conceito o exame da mais grave e perturbadora forma de infringência jurídica, que é, sem dúvida alguma, o desres-

(*) Comunicação apresentada ao Primeiro Congresso Internacional e às Terceiras Jornadas LatinoAmericanas de Direito Processual Civil, certames realizados, em São Paulo, no período de 10 a 15 de setembro de 1962, sob os auspícios do Instituto Brasileiro de Direito Processual Civil. Conclusões. A comunicação está desenvolvida em dezesseis ítens, acompanhados das notas e referências bibliográficas constantes do texto. 
peito ao dispositivo constitucional, fonte e base de tôda a arquitetônica da Nação polìticamente organizada.

Essa a grande tarefa do Poder Judiciário, porque a êle compete, em nosso regime, o exercício da função jurisdicional.

Não se diga que a possibilidade de impetração do mandado de segurança investe contra os alicerces institucionais do organismo judicante, pois o Judiciário, no processo da garantia constitucional, de natureza eminentemente pública, tem em seu prol, como nenhum outro poder do Estado, a prerrogativa de exercer a revisão dos seus próprios atos, atendidos os graus de hierarquia funcional e mercê do desenvolvimento da superposição das instâncias.

Cumpre, contudo, imprimir, na consciência dos nossos magistrados, a importância de que se reveste a grave missão de julgar, tendo-se em consideração as novas necessidades que rodeiam o preparo técnico e profissional dos candidatos aos quadros da Justiça. Em tal sentido, oportunos trabalhos têm vindo a lume, exaltando a conveniência de serem instituídos cursos especiais para perfeita seleção ao ingresso dos que se destinam às funções judiciárias (1).

Sendo o mandado de segurança um instrumento de excepcional aplicação, destinado a regular as relações do indivíduo em face do Estado, êle requer um trato especialíssimo da parte da autoridade jurisdicional. Se o Judiciário nada mais é "que um sistema de meios para fazer executar as leis; e a fidelidade à lei é a primeira obrigação dos tribunais", segundo a clássica lição de Bentham (2), não se olvide, todavia, que essa fidelidade não deve caracterizar um servilismo jungido à pura letra da lei, à fria e inerte indicação do legislador; mas cabe à magistratura vivificar o preceito em conformidade com os mais alevantados ideais de justiça.

O próprio processo, no seu mais alto sentido ou finalismo, é apenas um meio, uma instrumentalidade para atingir tal objetivo (3).

O contencioso constitucional tem, no mandado de segurança, o remédio adequado à defesa dos direitos da pessoa humana. Basta que, na sua aplicação, não se deixe o julgador empolgar por egoísmos injustificados, nem por soluções incompatíveis com a dignidade da fun. ção pública.

Assim sendo, o livre debate das idéias para a verificação dos pros e dos contras, na procura da melhor solução jurídica, assume, na hora presente, de tantas e tão profundas modificações sociais e políti-

(1) Cf. E. D. MONIZ DE ARAGÃO, Formação e Aperfeiçoamento de Juízes, "Revista de Direito Processual Civil", 3.0 vol., janeiro a junho de 1961, págs. 87 e segts. EDGAR DE MOURA BITTENCOURT, Recrułamenło de Juízes e a Preparaçâao das Profissóes Judiciárias, "Revista dos Tribunais", vol. 315, págs. 107 a 129.

(2) Cf. JÉRÉMIE BENTHAM, Oeuvres, De L’Organisation Judiciaire ef de la Codification (tome troisième), Bruxelas, 1840, pág. 7.

(3) Cf. GALENO LACERDA, Processo e Cultura, "Revista de Direito Processual Civil", 3.० vol., janeiro a junho de 1961, pág. 86. 
cas, significação de alta relevância, de que é vanguardeiro êste Congresso Internacional, realizado sob os auspícios da Escola Processual de São Paulo, fiel depositária das mais lídimas tradições da cultura jurídica brasileira.

\section{CONCLUSÕES}

Apresentamos, em esquema de conclusões, e como despretencioso subsídio ao estudo da garantia clausulada no art. 141, § 24, da Constituição Federal do Brasil, promulgada em 18 de setembro de 1946, os seguintes temas:

1) O ordenamento jurídico brasileiro admite, em casos excepcionais, o exercício da ação constitucional de mandado de segurança, desde que verificados, através do devido processo, os pressupostos de existência de direito líquido e certo não amparável por habeas corpus, violado ou ameaçado de violação por ato ilegal ou abusivo de poder de qualquer autoridade, incluídos nesta categoria os despachos ou decisões da lavra de Juízes e Tribunais no decorrer do procedimentalismo processual, quer no âmbito da chamada jurisdição volunfária, quer na espera da jurisdição puramente contenciosa.

2) O mandado de segurança não tem cabimento nas hipóteses em que haja recurso ordinário com efeito suspensivo previsto na lei decretada pela União.

3) A falta de suspensividade do recurso cabível não modifica - quadro jurídico, para o efeito de permitir, ou não, o emprêgo da garantia contra ato judicial ou jurisdicional, a não ser que êste se apresente com as características de ilegalidade ou abuso de poder, que, tìpicamente, justificam o cabimento do writ.

4) A correição, a que se refere a lei ordinária disciplinadora do mandado de segurança, deveria ser devidamente regulamen tada pelo legislativo federal, para situar-se no campo único e exclusivo das falhas e dos êrros ou abusos in procedendo, tumultuários da boa ordem processual, atingindo-se, com isso, uma salutar uniformidade de entendimento e aplicação dessa medida administrativa no seio da Federação brasileira.

5) A coisa julgada, obtida com base em dolo bilateral, pode ser atacada pelos terceiros interessados, que não interferiram no processo fraudulento, através do mandado de segurança.

6) De lege ferenda, conveniente será seja reduzido o prazo de decadência previsto pelo artigo 18 da Lei n. ${ }^{\circ} 1.533$, de 1951, relativamente à impetração do writ contra os atos judiciais.

A Recomenda-se, ainda, a facilitação, da melhor forma possível, no procedimentalismo do mandado de segurança, das partes 
que figurarem no processo, para que tenham ciência imediata, por parte do juiz havido como autoridade coatora, da impetração da medida excepcional.

B Igualmente, é de todo em todo recomendável, de jure condendo, a dilatação para dez dias do prazo das informações da autoridade.

7) Nos casos em que o recurso não tenha efeito suspensivo, poderia o legislador, de futuro, permitir, expressamente, a impetração do mandamus contra despacho ou decisão judicial para proteção de direito inconcusso, atendidos os demais pressupostos da norma da Constituição da República, dentro, porém, no prazo legalmente estabelecido para o recurso processual oponível, feita, desde logo, perante o juiz ou tribunal competente, por escrito, a devida opção pelo interessado. Curitiba, setembro de 1962. Ano do Cinqüentenário da Universidade Federal do Paraná.

\section{CONCLUSIONES}

Presentamos, en esquema de conclusiones, y como despretencioso subsídio al estudio de la garantía clausulada en el art. 141, § 24, de la Constitución Federal del Brasil, promulgada en 18 de Septiembre de 1946, los seguientes temas:

1) El ordenamiento jurídico brasileño admite, en casos excepcionales, el ejercicio de la acción constitucional del "mandado de segurança", desde que verificados, en el transcurso del debido proceso, los presupuestos de la existencia del derecho líquido y cierto no amparable por habeas corpus, violado o amenazado de violación por acto ilegal o abusivo de poder de cualquier Autoridad, incluidos en esta categoría los despachos o decisiones dictadas por los Juezes y Tribunales en el decorrer del procedimiento procesal, bien en el ambito de la llamada jurisdicción voluntaria, bien en la esfera de la jurisdicción puramente contenciosa.

2) El "mandado de segurança", no tiene procedencia en las hipótesis en que haya recurso ordinario con efecto suspensivo previsto en la Ley decretada por la Unión.

3) La falta de suspensibilidad del recurso adecuado no modifica el cuadro jurídico, para el efecto de permitir, o no, el empleo dela garantía contra acto judicial o jurisdiccional, a no ser que este se presente con las características de ilegalidad o abuso de poder, que típicamente, justifican la procedencia del writ.

4) La "correição", a que se refiere la Ley ordinaria disciplinadora del "mandado de segurança", deberia ser debidamente re- 
glamentada por el legislativo federal, para situarse en el campo único y exclusivo de las fallas y de los erros o abusos in procedendo, tumultuarios del buen orden procesal, atin giendose, con eso, una saludable uniformidad de entendimiento y aplicación de esa medida administrativa en el seno de la Federación brasileña.

5) La cosa juzgada, obtenida con base en dolo bilateral, puede ser atacada por los terceros interesados, que no interfirieron en el proceso fraudulento, a través del "mandado de segurança".

6) De lege ferenda, conveniente será sea reducido el plazo de decadencia previsto por el art. 18 de la Ley n. ${ }^{\circ} 1.533$, de 1951, relativamente a la impetración del writ contra los actos judiciales.

A Se recomienda, aun, la facilitación, de la mejor forma posible, en el procedimiento del "mandado de segurança", de las partes que figuraren en el proceso, para que tengan ciencia inmediata, por parte del Juez habido como autoridad coautora, de la impetración de la medida excepcional.

B Igualmente, es de todo por todo recomendable, de jure condendo, la dilatación para diez dias del plazo de las informaciones de la Autoridad.

7) En los casos en que el recurso no tenga efecto suspensible, podria el legislador, de futuro, permitir, expresamente, la impetración del mandamus contra despacho o decisión judicial para proteción del derecho incontestables atendidos los demás presupuestos de la norma de la Constitución de la República, dentro, sin embargo, en el plazo legalmente establecido para el recurso procesal oponible, hecha, desde luego, ante el Juez o Tribunal competente, por escrito, la debida opción por el interesado.

Curitiba, septiembre de 1962. - Año del 50 Aniversario de la Universidad del Paraná.

\section{CONCLUSIONI}

Presentiamo, in questo schema conclusivo, e come modesto sussidio allo studio della garanzia contenuta nell art. 141, § 24, della Costituzione Federale del Brasile, promulgata il 18 Settembre 1946, i seguenti temi:

1) L'ordinamento giuridico brasiliano ammette, in casi eccezionali, l'esercizio dell'azione costituzionale del "mandado de segurança", purché verificati, per mezzo di debito processo, i presupposti di esistenza di diritto liquido e certo non protetto dall habeas corpus, violato o minacciato di violazione per 
atto illegale o abusivo di potere di qualunque autorità, inclusi in questa categoria i dispacci o decisioni emanati da Giudici e Tribunali nel decorrere della procedura processuale, sia nell' ambito della cosí chiamata giurisdizione volontaria, sia nella sfera della giurisdizione puramente contenziosa.

2) II "mandado de segurança" non ha senso nelle ipotesi in cui si dia ricorso ordinario con effetto sospensivo previsto in legge decretada dall'Unione Federale.

3) La mancanza di sospensività del ricorso ammesso non modifica il quadro giuridico, agli effetti di permettere o no l'uso della garanzia contro atto giudiziale o giurisdizionale, a meno che questo si presenti con le caratteristiche d'illegalità o abuso di potere, che, tipicamente, giustificano l'uso del writ.

4) La "correição" cui si riferisce la legge ordinaria che disciplina il "mandado de segurança" dovrebbe essere debitamente regolata dal legislativo federale, per situarsi nel campo unico ed esclusivo delle deficienze e degi errori o abusi in procedendo, perturbatori del buon ordine processuale, attingendosi, con ciò, una salutare uniformità d'intendimento e di applicazione di questa misura amministrativa in seno alla $\mathrm{Fe}$ derazione brasiliana.

5) La cosa giudicata, ottenuta in base a dolo bilaterale, può essere impugnata da terzi interessati, che non interferirono nel processo fraudolento, per mezzo del "mandado de segurança".

6) De lege ferenda, sarà conveniente sia ridotto il termine di scadenza previsto dall'articolo 18 della Legge $n .^{\circ} 1.533$, del 1951, relativamente alla impetrazione del writ contro atti giudiziali.

A Si raccomanda, ancora, la facilitazione, nella migliore maniera possibile, nella procedura del "mandado de segurança", delle parti che figurano nel processo, affinché abbiano cognizione immediata, da parte del giudice avuto come autorità coattiva, della impetrazione della misura di eccezione.

B Ugualmente, è pienamente da raccomandare, de iure condendo, la estensione a dieci giorni del limite di tempo delle informazioni dell'autorità.

7) Nei casi in cui il ricorso non abbia effetto sospensivo, potrebbe il legislatore, in futuro, permettere, espressamente, l'impetrazione del mandamus contro dispacio o decisione giudiziale per protezione di diritto inconcusso, soddisfatti gli altri presupposti della norma della costituzione della Repubblica, entro, però, il termine legalmente stabilito per il ricorso 
processuale opponibili, fatta sibito, davanti al giudice o tribunale competente, e per iscritto, la debita opzione da parte dell'interessato.

Curitiba, Settembre de 1962. - Anno del Cinquantenario dell'Università del Paraná.

\section{CONCLUSIONS}

In a brief survey on our conclusions and, as an unpretentious subsidiary to the study of the right referred to in the clause of Article 141, § 24, of the Brazilian Federal Constitution, we wish to present the following themes:

1) The Brazilian judicial ordainment permits, in exceptional cases, the exercise of the constitutional act of "mandado de segurança" provided that, the presupposition of the existence of an unquestionable and undeniable right, not supported by any writ of habeas corpus, but violated or threatened with violation by an illegal or abusive act within the power of any authority that, also include the dispatches or decisions on part of Judges and Courts of Justice, during the course of the action at law within the bounds of the so-called voluntary jurisdiction, as well as within the sphere of the purely litigious jurisdiction in this category, has been duly verified.

2) The "mandado de segurança" has no legal standing in case of there being an ordinary appeal with a suspensive effect, foreseen by the Law of the Union.

3) The want of a suspensive effect through legal means, does not alter the judicial aspect to the effect of permitting, or not, the benefit of a right (guaranty) against a judicial or jurisdictional act, unless it presents the characteristics of illegality or abuse of power that amply justify the petition of the "mandado de segurança".

4) The "CORREIÇÃO", which the ordinary, disciplinary law of the "mandado de segurança" refers to, should be regulated by the Federal Legislative and, be placed within the sole and unique scope of the blunders and mistakes, or abuses "in procedendo", tumultuous of the good, legal precedure, attaining through it a sound uniformity of understanding and enforcement of the said administrative measure in the ambit of the Brazilian Federation.

5) The "res judicata", obtained on a basis of bilateral fraud, may be questioned by a third interested party, who had no interference in the fraudulent act, through the foresaid writ of the "mandado de segurança". 
6) De lege ferenda it will be convenient that the term of decadence foreseen in Article 18 of the Act 1.533, of 1951, concerning the petition of the writ against judicial proceedings, be shortened.

A) Facilities, as to the best possible ways of procedure of the "mandado de segurança" on the part of the parties that appear in the process are recommended in order that they may be notified at once by the judge who, in this case, is the legally constituted authority of the petition of the special measure.

B) De jure condendo an extension of ten days of the term for information on the part of the authorities, is equally expedient.

7) In cases where the recourse has not a suspensive effect, the legislator could, in future, allow the petition of the writ of "mandado de segurança" against the judicial dispatch or decision, as a protective and incontestable right, provided that all other presuppositions of the standard rule of the constitution of the Republic have been respected, however, within the legally established term for the opposing, processional recourse, the due option on part of the interested party drawn up, from the very first, in form of a written document before the judge or any other competent authority.

Curitiba, September 1962. - In the year of the FIFTIETH Anniversary of the University of Paraná. 